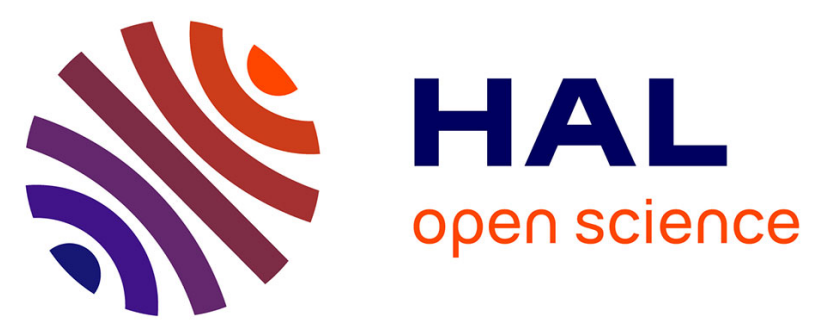

\title{
Occurrence of verocytotoxin-producing in the faeces of free-ranging wild lagomorphs in southwest Spain
} Remigio Martínez, Alfredo García, Jesús E. Blanco, Jorge Blanco, Joaquín Rey, Juan M. Alonso, Luis Gómez, Sergio Sánchez

\section{- To cite this version:}

Remigio Martínez, Alfredo García, Jesús E. Blanco, Jorge Blanco, Joaquín Rey, et al.. Occurrence of verocytotoxin-producing in the faeces of free-ranging wild lagomorphs in southwest Spain. European Journal of Wildlife Research, 2010, 57 (1), pp.187-189. 10.1007/s10344-010-0431-8 . hal-00624464

\section{HAL Id: hal-00624464 \\ https://hal.science/hal-00624464}

Submitted on 18 Sep 2011

HAL is a multi-disciplinary open access archive for the deposit and dissemination of scientific research documents, whether they are published or not. The documents may come from teaching and research institutions in France or abroad, or from public or private research centers.
L'archive ouverte pluridisciplinaire HAL, est destinée au dépôt et à la diffusion de documents scientifiques de niveau recherche, publiés ou non, émanant des établissements d'enseignement et de recherche français ou étrangers, des laboratoires publics ou privés. 


\title{
Occurrence of verocytotoxin-producing Escherichia coli in the faeces of free-ranging wild lagomorphs in southwest Spain
}

\author{
Remigio Martínez • Alfredo García • Jesús E. Blanco • \\ Jorge Blanco • Joaquín Rey • Juan M. Alonso • \\ Luis Gómez • Sergio Sánchez
}

Received: 13 July 2010 /Revised: 29 August 2010 /Accepted: 1 September 2010 /Published online: 18 September 2010

(C) Springer-Verlag 2010

\begin{abstract}
Verocytotoxin-producing Escherichia coli (VTEC) is an important group of emerging food-borne pathogens and represents a major public health concern worldwide. The aim of this work was to analyse faecal samples from hunted wild lagomorphs for the presence of E. coli $\mathrm{O} 157: \mathrm{H} 7$ and nonO157 VTEC. During two hunting seasons, faecal samples from 241 animals were collected, including wild rabbit (Oryctolagus cuniculus) and hare (Lepus granatensis) and were examined for VTEC. Overall, VTEC were detected and
\end{abstract}

Communicated by C. Gortázar

R. Martínez · J. Rey · J. M. Alonso · S. Sánchez

Patología Infecciosa y Epidemiología, Departamento de Sanidad

Animal, Facultad de Veterinaria, Universidad de Extremadura,

10071 Cáceres, Spain

\author{
A. García \\ Producción Animal, Centro de Investigación Finca \\ La Orden-Valdesequera, \\ Junta de Extremadura, \\ 06187 Badajoz, Spain \\ J. E. Blanco $\cdot$ J. Blanco \\ Laboratorio de Referencia de E. coli (LREC), \\ Departamento de Microbiología y Parasitología, \\ Universidad de Santiago de Compostela, \\ 27002 Lugo, Spain \\ L. Gómez \\ Histología y Anatomía Patológica, Departamento de Medicina \\ Animal, Facultad de Veterinaria, Universidad de Extremadura, \\ 10071 Cáceres, Spain \\ Present Address: \\ S. Sánchez $(\square)$ \\ Instituto de Investigación en Recursos Cinegéticos (IREC), \\ CSIC-UCLM-JCCM, Ronda de Toledo $\mathrm{s} / \mathrm{n}$, \\ 13071 Ciudad Real, Spain \\ e-mail: sergio.sanchezprieto@uclm.es
}

isolated in four $(1.66 \%)$ of the 241 animals sampled. E. coli O157:H7 was isolated only from one of $124(0.81 \%)$ wild rabbit faecal samples while non-O157 VTEC were isolated from two of $124(1.61 \%)$ wild rabbit faecal samples and one of $117(0.85 \%)$ hare faecal samples. VTEC isolates obtained in the present study (four in total) belonged to four different $\mathrm{O}: \mathrm{H}$ serotypes, including two serotypes $\left(\mathrm{O} 84: \mathrm{H}^{-}\right.$and $\mathrm{O} 157$ : H7) previously associated with human infection and in particular with causing the life-threatening haemolyticuraemic syndrome. Although these results indicate a low prevalence of VTEC infection in free-ranging wild lagomorphs, they may play an important role as a source of exposure to human beings and livestock and as a vehicle for dispersing these pathogens. These findings have implications for the zoonotic risk to hunters, people consuming meat from wild animals and others in contact with wild animal faeces, and also in the development of programmes for controlling VTEC at the farm level.

Keywords Verocytotoxin-producing Escherichia coli (VTEC) - E. coli O157:H7 · Wild lagomorphs · Oryctolagus cuniculus $\cdot$ Lepus granatensis

Verocytotoxin-producing Escherichia coli (VTEC) has recently emerged as an important food-borne pathogen. Human diseases ranging from mild diarrhoea to haemorrhagic colitis and the life-threatening haemolytic-uraemic syndrome (HUS) can be caused by VTEC, typically affecting infants, young children and the elderly (Paton and Paton 1998). The pathogenic capacity of VTEC resides in a number of virulence factors, including verocytotoxins (VT1 and VT2), intimin, enterohaemolysin and the autoagglutinating adhesin (Saa) (Gyles 2007). Serotype O157:H7 especially represents a major public health concern worldwide; however, non-O157 VTEC should not be overlooked 
in human disease investigations because non-O157 VTEC strains are more prevalent than E. coli $\mathrm{O} 157: \mathrm{H} 7$ in the faeces of meat-producing animals, indicating that humans are more likely to become exposed to such strains (Blanco et al. 2004a; Djordjevic et al. 2004). Although healthy domestic ruminants (mainly cattle) are the best recognised animal reservoir for VTEC (Blanco et al. 2004b; Sánchez et al. 2010a), VTEC strains have also been isolated from wildlife, especially from deer (Renter et al. 2001; Sánchez et al. 2009). The isolation of E. coli $\mathrm{O} 157: \mathrm{H} 7$ and nonO157 VTEC from wild rabbits has been previously reported (Pritchard et al. 2001; Scaife et al. 2006) and colonisation of laboratory rabbits by VTEC has also been demonstrated in experimental laboratory infections (Li et al. 1993; García and Fox 2003). The aim of the current study was to analyse faecal samples from wild rabbits and hares killed by hunters and intended for their own consumption for the presence of E. coli $\mathrm{O} 157: \mathrm{H} 7$ and non-O157 VTEC.

During the 2007-2008 and 2008-2009 hunting seasons (from October to January), collaborating hunters collected faecal samples from wild lagomorphs harvested in different game estates in the Extremadura region in southwest Spain. They were provided with sampling equipment as well as step-by-step instructions for sample collection before the start of every season. When harvesting the animal, the hunters were asked to use a pair of disposable gloves, insert a sterile swab into the rectum of the animal, collect a faecal sample (one per animal) by rapid in-and-out motion and transfer the swab to a tube containing Cary-Blair transport medium (DeltaLab). The samples were transported to the laboratory under refrigeration and placed in culture media within 24 h. Overall, wild rabbit (Oryctolagus cuniculus) provided 124 samples and 117 came from hare (Lepus granatensis). The samples were plated onto both MacConkey (MAC) and cefixime tellurite sorbitol MacConkey (CTSMAC) agars (Oxoid). For isolation of non-O157 VTEC, ten suspect $E$. coli colonies from MAC plates were tested for the genes encoding VT1 and VT2 toxins (VT1 and VT2 genes) by PCR as previously described (Rey et al. 2003). For isolation of $E$. coli $\mathrm{O} 157: \mathrm{H} 7$, after a selective enrichment step involving immunomagnetic separation, ten non-sorbitolfermenting colonies from the CTSMAC plates were tested for the genes encoding $\mathrm{O} 157$ and $\mathrm{H} 7$ antigens as previously described (García-Sánchez et al. 2007). The resulting VTEC isolates were confirmed biochemically as $E$. coli by the API $20 \mathrm{E}$ system (bioMérieux) and tested for additional virulence genes (eae, ehxA and $s a a$ ). The identification of $\mathrm{O}$ and $\mathrm{H}$ antigens (serotyping) in VTEC isolates was carried out as described by Guinée et al. (1981) using the full range of O (O1 to $\mathrm{O} 185)$ and $\mathrm{H}(\mathrm{H} 1$ to $\mathrm{H} 56)$ antisera.

Overall, VTEC were detected and isolated in four $(1.66 \%)$ of the 241 animals sampled. E. coli $\mathrm{O} 157: \mathrm{H} 7$ was isolated only from one of $124(0.81 \%)$ wild rabbit faecal samples while non-O157 VTEC were isolated from two of $124(1.61 \%)$ wild rabbit faecal samples and one of $117(0.85 \%)$ hare faecal samples (Table 1$)$. All isolates obtained in the present study (four in total) were further characterised (Table 1). They belonged to four different $\mathrm{O}$ : $\mathrm{H}$ serotypes, including two serotypes $(\mathrm{O} 84: \mathrm{H}-$ and $\mathrm{O} 157$ : H7) previously associated with human infection and in particular with causing HUS (http://www.lugo.usc.es/ecoli; http://www.microbionet.com.au/vtectable.htm). The PCR procedure indicated that one isolate carried the VT1 gene and the rest carried the VT2 gene. The ehxA and eae genes were detected only in the E. coli $\mathrm{O} 157: \mathrm{H} 7$ isolate and none of the isolates contained the saa gene.

The results of the present study suggest a low prevalence of VTEC infection in free-ranging wild lagomorphs in this area of Spain, although it is important to note that this was not a random survey but only biased to areas used by hunters. Prevalence rates of E. coli O157:H7 and non-O157 VTEC obtained in this study are much lower than those currently observed in domestic ruminant species such as cattle, sheep or goats (Oporto et al. 2008; Orden et al. 2008; Sánchez et al. 2010a). This is not surprising as livestock are much more intensively reared and the potential for exposure and colonisation is much greater than for most wildlife; however, VTEC strains have also been isolated from other wild animal species, such as deer and wild boars (Sánchez et al. 2009, 2010b). Wild rabbits and hares are

Table 1 Results of faecal culture for VTEC, serotypes and virulence genes of VTEC isolates recovered from wild lagomorphs

\begin{tabular}{|c|c|c|c|c|c|c|}
\hline \multirow[t]{2}{*}{ Animal } & \multirow[t]{2}{*}{ Number cultured } & \multicolumn{2}{|l|}{ E. coli $\mathrm{O} 157: \mathrm{H} 7$} & \multicolumn{3}{|l|}{ Non-O157 VTEC } \\
\hline & & Number positive (\%) & Virulence genes & Number positive (\%) & Serotype & Virulence genes \\
\hline \multirow[t]{2}{*}{ Wild rabbit } & 124 & $1(0.81)$ & VT2 eae ehxA & $2(1.61)$ & O22:HNT & VT2 \\
\hline & & & & & $\mathrm{O} 117: \mathrm{H} 8 / \mathrm{H} 21^{\mathrm{a}}$ & VT2 \\
\hline Hare & 117 & 0 & & $1(0.85)$ & $\mathrm{O} 84: \mathrm{H}^{-\mathrm{b}}$ & VT1 \\
\hline
\end{tabular}

$V T 1 / V T 2$ genes encoding VT1 and VT2 toxins, eae gene encoding intimin, ehxA gene encoding enterohaemolysin, $H N T$ H antigen non-typeable

${ }^{\mathrm{a}}$ The isolate cross-reacted with the respective $\mathrm{H}$ antisera

${ }^{\mathrm{b}}$ Serotype previously associated with human infection and in particular with causing HUS 
commonly found in areas inhabited by human beings and livestock and consequently may share common sources of exposure to VTEC. Indeed, wild rabbits' faeces have been associated with $E$. coli $\mathrm{O} 157: \mathrm{H} 7$ infection in visitors to a wildlife park in the United Kingdom (Pritchard et al. 2001). Furthermore, indistinguishable genotypes of E. coli O157: H7 have been identified (by the pulsed-field gel electrophoresis technique) in cattle and wild rabbits occupying the same range, indicating either a common source of exposure or transmission from one species to the other (Pritchard et al. 2001). In the studied areas, wild rabbit and hare populations usually have access to the same pastures as cattle and sheep, although they have no contact with freeranging wild ruminants. Therefore, environmental contamination with VTEC excreted by domestic livestock and indirect transmission to wild lagomorphs from the contaminated environment could explain the occurrence of VTEC in their faeces. In addition, Miko et al. (2009) recently reported the contamination of meat from wild animals (including hare meat) with VTEC and concluded that such strains should be recognised as a public health problem. Consequently, wild lagomorphs such as wild rabbits and hares may play an important role as a source of VTEC in the environment, as a source of exposure to human beings and livestock and as a vehicle for dispersing these pathogens. These findings have implications for the zoonotic risk to hunters, people consuming meat from wild animals and others in contact with wild animal faeces, and also in the development of programmes for controlling VTEC at the farm level.

Acknowledgements The authors thank hunters for indicating a willingness to participate in sample collection. The authors also thank R. Rubio for skilful technical assistance. This study was partially supported by grants from the Junta de Extremadura and FEDER (grants 3PR05A009-III Plan Regional de Investigación and PRI09A022). R. Martínez acknowledges the Junta de Extremadura for his research fellowship (PRE06053). S. Sánchez acknowledges the Consejería de Educación y Ciencia de la Junta de Comunidades de Castilla-La Mancha and Fondo Social Europeo for his research fellowship (09/02-C).

\section{References}

Blanco JE, Blanco M, Alonso MP, Mora A, Dahbi G, Coira MA, Blanco J (2004a) Serotypes, virulence genes, and intimin types of Shiga toxin (verotoxin)-producing Escherichia coli isolates from human patients: prevalence in Lugo, Spain, from 1992 through 1999. J Clin Microbiol 42:311-319

Blanco M, Blanco JE, Mora A, Dahbi G, Alonso MP, González EA, Bernárdez MI, Blanco J (2004b) Serotypes, virulence genes, and intimin types of Shiga toxin (verotoxin)-producing Escherichia coli isolates from cattle in Spain and identification of a new

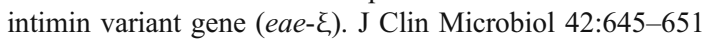

Djordjevic SP, Ramachandran V, Bettelheim KA, Vanselow BA, Holst P, Bailey G, Hornitzky MA (2004) Serotypes and virulence gene profiles of Shiga toxin-producing Escherichia coli strains isolated from feces of pasture-fed and lot-fed sheep. Appl Environ Microbiol 70:3910-3917

García A, Fox JG (2003) The rabbit as a new reservoir host of enterohemorrhagic Escherichia coli. Emerg Infect Dis 9:1592-1597

García-Sánchez A, Sánchez S, Rubio R, Pereira G, Alonso JM, Hermoso de Mendoza J, Rey J (2007) Presence of Shiga toxinproducing E. coli O157:H7 in a survey of wild artiodactyls. Vet Microbiol 121:373-377

Guinée PAM, Jansen WH, Wadström T, Sellwood R (1981) Escherichia coli associated with neonatal diarrhoea in piglets and calves. In: Leeww PW, Guinée PAM (eds) Laboratory diagnosis in neonatal calf and pig diarrhoea: current topics in veterinary and animal science, vol 13 . Martinus-Nijhoff, The Hague, pp 126-162

Gyles CL (2007) Shiga toxin-producing Escherichia coli: an overview. J Anim Sci 85:E45-E62

Li Z, Bell C, Buret A, Robins-Browne R, Stiel D, O'Loughlin E (1993) The effect of enterohemorrhagic Escherichia coli O157: $\mathrm{H} 7$ on intestinal structure and solute transport in rabbits. Gastroenterology 104:467-474

Miko A, Pries K, Haby S, Steege K, Albrecht N, Krause G, Beutin L (2009) Assessment of Shiga toxin-producing Escherichia coli isolates from wildlife meat as potential pathogens for humans. Appl Environ Microbiol 75:6462-6470

Oporto B, Esteban JI, Aduriz G, Juste RA, Hurtado A (2008) Escherichia coli $\mathrm{O} 157: \mathrm{H} 7$ and non-O157 Shiga toxin-producing E. coli in healthy cattle, sheep and swine herds in Northern Spain. Zoonoses Public Health 55:73-81

Orden JA, Cortés C, Horcajo P, De la Fuente R, Blanco JE, Mora A, López C, Blanco J, Contreras A, Sánchez A, Corrales JC, Domínguez-Bernal G (2008) A longitudinal study of verotoxinproducing Escherichia coli in two dairy goat herds. Vet Microbiol 132:428-434

Paton JC, Paton AW (1998) Pathogenesis and diagnosis of Shiga toxin-producing Escherichia coli infections. Clin Microbiol Rev 11:450-479

Pritchard GC, Williamson S, Carson T, Bailey JR, Warner L, Willshaw G, Cheasty T (2001) Wild rabbits - a novel vector for verocytotoxigenic Escherichia coli O157. Vet Rec 149:567

Renter DG, Sargeant JM, Hygnstorm SE, Hoffman JD, Gillespie JR (2001) Escherichia coli O157:H7 in free-ranging deer in Nebraska. J Wildl Dis 37:755-760

Rey J, Blanco JE, Blanco M, Mora A, Dahbi G, Alonso JM, Hermoso M, Hermoso J, Alonso MP, Usera MA, González EA, Bernárdez MI, Blanco J (2003) Serotypes, phage types and virulence genes of Shiga-producing Escherichia coli isolated from sheep in Spain. Vet Microbiol 94:47-56

Sánchez S, García-Sánchez A, Martínez R, Blanco J, Blanco JE, Blanco M, Dahbi G, Mora A, Hermoso de Mendoza J, Alonso JM, Rey J (2009) Detection and characterisation of Shiga toxinproducing Escherichia coli other than Escherichia coli O157:H7 in wild ruminants. Vet $\mathrm{J}$ 180:384-388

Sánchez S, Martínez R, García A, Benítez JM, Blanco J, Blanco JE, Blanco M, Dahbi G, López C, Mora A, Alonso JM, Rey J (2010a) Variation in the prevalence of non-O157 Shiga toxinproducing Escherichia coli in four sheep flocks during a 12month longitudinal study. Small Rum Res 93:144-148

Sánchez S, Martínez R, García A, Vidal D, Blanco J, Blanco M, Blanco JE, Mora A, Herrera-León S, Echeita A, Alonso JM, Rey J (2010b) Detection and characterisation of O157:H7 and non-O157 Shiga toxin-producing Escherichia coli in wild boars. Vet Microbiol 143:420-423

Scaife HR, Cowan D, Finney J, Kinghorn-Perry SF, Crook B (2006) Wild rabbits (Oryctolagus cuniculus) as potential carriers of verocytotoxin-producing Escherichia coli. Vet Rec 159:175-178 